\title{
Arctiinae (Lepidoptera: Erebidae) in the state of Rio de Janeiro, Brazil
}

\author{
Milena de Sousa Nascimento ${ }^{1,3}$, Viviane Gianluppi Ferro ${ }^{2}$ \& Ricardo Ferreira Monteiro ${ }^{1}$ \\ ${ }^{1}$ Universidade Federal do Rio de Janeiro, Instituto de Biologia, Departamento de Ecologia, \\ Laboratório de Ecologia de Insetos, CP 68020, 21941-590, Rio de Janeiro, RJ, Brazil. \\ ${ }^{2}$ Universidade Federal de Goiás, Instituto de Ciências Biológicas, Departamento de Ecologia, \\ 74690-900, Goiânia, GO, Brazil. \\ ${ }^{3}$ Corresponding author: Milena de Sousa Nascimento, e-mail: milenasnascimento@gmail.com
}

NASCIMENTO, M.S., FERRO, V.G., MONTEIRO, R.F. Arctiinae (Lepidoptera: Erebidae) in the state of Rio de Janeiro, Brazil. Biota Neotropica. 16(2): e20150112. http://dx.doi.org/10.1590/1676-0611-BN-2015-0112

\begin{abstract}
This study describes the composition and distribution of the Arctiinae species (Lepidoptera: Erebidae) in Rio de Janeiro, generating the first list of Arctiinae species in the state. We assessed the variations in species composition and the different vegetation types in the municipalities of Rio de Janeiro. Data were collected primarily through surveys of museums and publication lists of species. We also conducted field sampling in March and September 2010. Of the 2,077 records covering 28 municipalities, 679 Arctiinae species were found in Rio de Janeiro state and were divided into two tribes and 220 genera. The location with the highest number of species recorded was Itatiaia, with 362 species, followed by Petrópolis and Angra dos Reis, with 320 and 306 species, respectively. Thirty-four percent ( $n=230$ ) of the species recorded were exclusive, i.e., occurred in only one location. The lowest dissimilarity values were observed between neighboring municipalities with the same type of plant formation, such as Petrópolis and Teresópolis (19\%) or Itatiaia and Resende (24\%). Some municipalities slightly further apart geographically, but with the same type of plant formation, also showed low levels of dissimilarity, for example, Petropolis and Resende (29\%). However, most locations showed intermediate dissimilarity values of $40-60 \%$, and in some cases, this figure rose to $96 \%$. In the state of Rio de Janeiro, irrespective of its small geographical size and the predominance of a unique ecosystem, the Atlantic Forest shows a wide variation in relief, which may explain the high beta diversity values. Despite the large number of Arctiinae species recorded in Rio de Janeiro, few species were identified in areas with important forest remnants, such as Guapimirim, Nova Iguaçu, and Campos dos Goitacazes. Some regions of the northwestern part of the state were also subsampled. It is likely that new records of Arctiinae still exist in these locations, further increasing the list of Arctiinae species in Rio de Janeiro. Keywords: Beta diversity of moths, List of species, Atlantic Forest.
\end{abstract}

NASCIMENTO, M.S., FERRO, V.G., MONTEIRO, R.F. Arctiinae (Lepidoptera: Erebidae) no estado do Rio de Janeiro, Brasil. Biota Neotropica. 16(2): e20150112. http://dx.doi.org/10.1590/1676-0611-BN-2015-0112

Resumo: Arctiinae (Lepidoptera: Erebidae) no estado do Rio de Janeiro, Brasil. O presente trabalho teve como objetivo descrever a composição e distribuição de espécies de Arctiinae (Lepidoptera: Erebidae) no estado do Rio de Janeiro, gerando a primeira lista de espécies de Arctiinae para o estado. Avaliou-se também a variação na composição de espécies nos municípios e nas diferentes formações vegetais do estado. Os dados foram obtidos através de levantamentos em museus e de publicações de listas de espécies. Foram também realizadas coletas de campo nos meses de março e setembro de 2010. De um total de 2.077 registros, abrangendo 28 municípios, encontrou-se 679 espécies de Arctiinae para o estado do Rio de Janeiro, distribuídas em duas tribos e 220 gêneros. O município com o maior número de espécies foi Itatiaia, com 362 espécies, seguido de Petrópolis e Angra dos Reis, com 320 e 306 espécies, respectivamente. Trinta e quatro por cento $(n=230)$ das espécies de Arctiinae registradas tiveram distribuição exclusiva, ou seja, ocorreram em apenas uma localidade. Os menores valores de dissimilaridade foram observados entre municípios próximos e localizados sob o mesmo tipo de formação vegetal, como Petrópolis e Teresópolis (19\%) ou Itatiaia e Resende (24\%). Alguns municípios mais afastados geograficamente, mas ainda localizados sob o mesmo tipo de formação vegetal, apresentaram também baixos valores de dissimilaridade, como Petrópolis e Resende (29\%), por exemplo. Entretanto, a maior parte dos municípios apresentou valores intermediários de dissimilaridade, entre 40 e $60 \%$, e em alguns casos esse valor chegou até a 96\%. O estado do Rio de Janeiro, mesmo com sua pequena dimensão geográfica e predomínio de um único ecossistema, a Mata Atlântica, apresenta uma grande variação no seu relevo, o que pode explicar alguns valores altos de diversidade beta. Apesar da 
grande quantidade de espécies de Arctiinae registrada para o estado do Rio de Janeiro, foram identificadas algumas localidades com remanescentes florestais importantes, como Guapimirim, Nova Iguaçu e Campos dos Goitacazes, e também algumas regiões do noroeste do estado ainda subamostradas. É bem provável que nessas localidades sejam encontrados novos registros de Arctiinae, aumentando ainda mais a lista de espécies de Arctiinae do estado do Rio de Janeiro.

Palavras-chave: Diversidade Beta de mariposas, Lista de espécies, Mata Atlântica.

\section{Introduction}

The Atlantic Forest biome is the second most biodiverse forest complex in Brazil, behind only the Amazon Forest (Ab'Sáber 2005). Originally, the Atlantic Forest covered more than 1 million $\mathrm{km}^{2}$ (SOS Mata Atlântica \& INPE 2015). Today, the biome covers only about $8 \%$ of its original area, representing approximately $1 \%$ of the national territory (SOS Mata Atlântica \& INPE 2015). Due to the extensive habitat loss and the high degree of endemism, the Atlantic Forest is considered a hotspot of biodiversity (Myers et al. 2000, Galindo-Leal \& Câmara 2005) and is one of the most threatened forests in the world (Oliveira-Filho \& Fontes 2000). The state of Rio de Janeiro, which had $100 \%$ of its area inside the Atlantic Forest, has only about $20 \%$ of its area covered by remnants of this biome today (SOS Mata Atlântica \& INPE 2015). The Atlantic Forest in the state of Rio de Janeiro includes different vegetation types and can be divided into major floristic blocks, such as dense rainforest (lowland, hillside, and altitude forests), semi-deciduous forest (forests inland plateaus), and associated ecosystems (salt marshes and mangroves) (SOS Mata Atlântica \& INPE 2015).

The Atlantic Forest is considered one of the most studied forests among Brazilian biomes, probably because of its proximity to major research centers. However, many gaps still exist, particularly in very diverse groups, such as insects (Lewinsohn \& Prado 2004). The order Lepidoptera is among the major groups of invertebrates in terms of published inventories, but much of the work has focused on butterflies (Lewinsohn \& Prado 2004). In the state of Rio de Janeiro, even with a high concentration of research centers and a large area of preserved Atlantic Forest, relatively few studies have been conducted on Lepidoptera fauna, except for the publications by Zikán \& Zikán (1968), Monteiro et al. (2004) and the lists of Pieridae species in Monteiro et al. (2009) and of Lycaenidae in Duarte et al. (2009).

The Arctiinae subfamily, as well as other moth and butterfly families, has been the subject of many studies, as they are suitable for studies on environmental impact and change models, are easy to collect and identify, and have a short lifecycle (Lewinsohn et al. 2005). About 11,000 Arctiinae species exist in the world (Jacobson \& Weller 2002), of which approximately 6,000 species occur in the Neotropics and 1,400 in Brazil (Ferro \& Diniz 2010). In a recent study, Vincent \& Laguerre (2014) published a catalog of the Neotropical Arctiini (except Ctenuchina and Euchromiina) in which presents an updated list of neotropical tiger moths, with 2,404 species of Arctiini. In Brazil, there are several studies about tiger moths, in different biomas like Savanas (Ferro \& Diniz 2007, Ferro\& Diniz 2010, Moreno et al. 2015), the Amazon Forest (Teston \& Delfina 2010, Delfina \& Teston 2013, Teston \& Correa, 2015) and even in the Atlantic Forest (Ferro \& Teston 2009, Ferro \& Melo 2011, Ferro \& Romanowski, 2012, Zenker et al. 2015). In general, these works address the richness, diversity and species composition of Arctiinae in certain areas, but there are few studies that compile lists of species for Brazilian states. Therefore, there have been no reviews that have summarized the existing knowledge about this family in the state of Rio de Janeiro. Thus, we generated a list of Arctiinae species for the state of Rio de Janeiro and investigated the richness, composition, and species similarity in the different plant formations of the state.

\section{Materials and Methods}

Arctiinae records for the state of Rio de Janeiro (i.e., the presence of a species in a given locality/municipality) were obtained predominantly from specimens deposited in the following Brazilian collections: (1) Entomological Collection of Instituto Oswaldo Cruz; (2) Museu Nacional, Universidade Federal do Rio de Janeiro; (3) Entomological Collection of Laboratório de Ecologia de Insetos, Universidade Federal do Rio de Janeiro; (4) Entomological Collection Padre Jesus Santiago Moure, Universidade Federal do Paraná; (5) Museu de Zoologia, Universidade de São Paulo; (6) Museu Paraense Emilio Goeldi; and (7) Vitor Becker's collection. Specimens with dubious provenance and identification were not considered. The collection labels of many specimens did not have the geographic coordinates and altitudes of the localities. In such cases, we obtained this information through the "Splink" information system, developed by the Reference Center on Environmental Information (http://splink.cria.org.br/geoloc?criaLANG $=\mathrm{pt}$ ).

We also used data from published lists of Arctiinae species (Zikán \& Zikán 1968, Monteiro et al. 2004) and samplings. The moths were sampled in protected areas in the municipalities of Casimiro de Abreu (Reserva Biológica União), Nova Iguaçu (Reserva Biológica Tinguá), and Teresópolis (Parque Nacional da Serra dos Órgãos). Samplings were conducted during the end of the rainy season (March 2010) and the late dry season (September 2010). These samplings were made during newmoon nights, using a 2 -m-wide $\times 1.5$-m-high white sheet and a $250 \mathrm{~W}$ mixed light lamp. The lamp was lit one hour after sunset and was connected to a power generator for two hours. The moths were identified through the literature (Watson \& Goodger 1986, Piñas Rubio et al. 2000, Piñas Rubio \& Manzano 2003) and by a comparison with the digital images of deposited species in the Becker's collection, whose identifications were confirmed by a comparison of the types.

The second order Jackknife and Chao 2 non-parametric estimators were used for estimating Arctiinae richness in the state of Rio de Janeiro. Moreover, the variation in species composition of these moths between different vegetation types was assessed using the Simpson's beta diversity index. This index was selected because it is less influenced by differences in species richness between samples (Koleff et al. 2003). Municipalities with Arctiinae records were categorized according to their predominant vegetation type, following the classification of SOS Mata Atlântica \& INPE (2015). The vegetation types considered were: (1) altitude forests: formations of dense rainforests located at elevations above $200 \mathrm{~m}$; (2) lowland forests: formations of dense rainforests located at low altitudes (up to $200 \mathrm{~m}$ ), including salt marshes and floodplain forests, which are predominantly coastal 
vegetation on sandy soil; and (3) mixed formations: municipalities that have both lowland forests and altitude forests. Statistical analyses were performed using $\mathrm{R}$ software ( $\mathrm{R}$ Development Core Team 2009).

\section{Results}

We obtained 2,077 Arctiinae records for the state of Rio de Janeiro, including $28(30 \%)$ municipalities in the state. In total, 679 Arctiinae species were recorded for the state of Rio de Janeiro, which were divided into two tribes and 220 genera. The list of Arctiinae species in each municipality of the state of Rio de Janeiro is presented in Appendix 1. The estimations of second order Jackknife richness and Chao 2 show the existence of 916 and 1,037 Arctiinae species in the state, respectively. Therefore, according to the Chao 2 estimate, which is the most conservative index, our species list represented $74 \%$ of the expected Arctiinae fauna.

The location with the highest number of recorded species was Itatiaia, with 362 species (Table 1). The municipalities of Petrópolis, Angra dos Reis, Rio de Janeiro, and Teresópolis also showed high species richness of Arctiinae (320, 306, 239, and 207, respectively) (Table 1). The distribution of Arctiinae species in the municipalities of Rio de Janeiro was quite heterogeneous, as the three richest municipalities accounted for $86 \%$ of all Arctiinae species in the state. Of the 28 municipalities in the state with Arctiinae records, 46\% ( $\mathrm{n}=$ 13) had less than 15 species and only $21 \%(n=6)$ had more than 100 species (Figure 1).

Aclytia heber (Cramer 1780) had the highest number of records throughout the study, occurring in 14 municipalities. Ilipa tengyra (Walker 1854) (12 municipalities), Pionia lycoides (Walker 1854) (11 municipalities), and Dycladia lucetius (Cramer 1782) (11 municipalities) were also very common in the state. Thirty-four percent $(n=230)$ of the Arctiinae species occurred in only one location. Itatiaia had the highest number of exclusive species $(n=96$ or $26.5 \%$ ).

Comparing the species composition of Arctiinae in different vegetation types in the state of Rio de Janeiro, the largest number of recorded species was observed in the altitude forests formations (574 species), followed by mixed formations (418 species), whereas lowland forests formations only presented 139 species. The dissimilarity of species was low within the three types of plant formations evaluated (Table 3). The smallest difference between the Arctiinae compositions was observed between the altitude forests and the mixed formations (Table 2).

Table 1. Arctiinae species richness in the municipalities of the state of Rio de Janeiro which had records of these moths and the percentage of exclusive species for each locality. Coordinates (in decimal degrees; datum SAD69), altitudes and vegetation types of each locality are also presented.

\begin{tabular}{|c|c|c|c|c|c|c|}
\hline \multirow[t]{2}{*}{ Municipality } & \multicolumn{2}{|c|}{ Coordinates } & \multirow[t]{2}{*}{ Altitude (m) } & \multirow[t]{2}{*}{ Vegetation type } & \multirow[t]{2}{*}{ Richness } & \multirow[t]{2}{*}{ Exclusive species (\%) } \\
\hline & LAT & LONG & & & & \\
\hline Angra dos Reis & $-23,0067$ & $-44,3181$ & 6 & Mixed formation & 306 & 9.8 \\
\hline Armação dos Búzios & $-22,7469$ & $-41,8817$ & 3 & Lowland forest & 4 & 0 \\
\hline Arraial do Cabo & $-22,9661$ & $-42,0278$ & 8 & Lowland forest & 11 & 0 \\
\hline Barra Mansa & $-22,5442$ & $-44,1714$ & 381 & Altitude forest & 1 & 0 \\
\hline Cachoeiras de Macacu & $-22,4625$ & $-42,6531$ & 60 & Mixed formation & 91 & 9.9 \\
\hline Campos dos Goytacazes & $-21,7542$ & $-41,3244$ & 13 & Lowland forest & 1 & 0 \\
\hline Carapebus & $-22,1872$ & $-41,6611$ & 15 & Lowland forest & 32 & 0 \\
\hline Casimiro de Abreu & $-22,4806$ & $-42,2042$ & 17 & Lowland forest & 8 & 12.5 \\
\hline Duque de Caxias & $-22,7856$ & $-43,3117$ & 19 & Lowland forest & 1 & 0 \\
\hline Guapimirim & $-22,5372$ & $-42,9819$ & 48 & Altitude forest & 5 & 0 \\
\hline Itatiaia & $-22,4961$ & $-44,5633$ & 600 & Altitude forest & 362 & 26.5 \\
\hline Macaé & $-22,3708$ & $-41,7869$ & 2 & Lowland forest & 32 & 0 \\
\hline Magé & $-22,6528$ & $-43,0406$ & 5 & Lowland forest & 33 & 6.1 \\
\hline Mangaratiba & $-22,9597$ & $-44,0406$ & 18 & Mixed formation & 47 & 4.3 \\
\hline Maricá & $-22,9194$ & $-42,8186$ & 5 & Lowland forest & 41 & 7.3 \\
\hline Niterói & $-22,8833$ & $-43,1036$ & 5 & Lowland forest & 3 & 0 \\
\hline Nova Friburgo & $-22,2819$ & $-42,5311$ & 846 & Altitude forest & 171 & 8.2 \\
\hline Nova Iguaçu & -22.7592 & -43.4511 & 25 & Lowland forest & 5 & 40.0 \\
\hline Petrópolis & $-22,5050$ & $-43,1786$ & 809 & Altitude forest & 320 & 9.1 \\
\hline Resende & $-22,4689$ & $-44,4467$ & 407 & Altitude forest & 55 & 5.5 \\
\hline Rio de Janeiro & $-22,9028$ & $-43,2075$ & 2 & Mixed formation & 239 & 9.6 \\
\hline Santo Antônio de Pádua & $-21,5394$ & $-42,1803$ & 86 & Mixed formation & 3 & 33.3 \\
\hline São João do Meriti & $-22,4814$ & $-43,222$ & 19 & Lowland forest & 2 & 0 \\
\hline Silva Jardim & -22.6508 & -42.3917 & 35 & Lowland forest & 51 & 21.6 \\
\hline Tanguá & $-22,7303$ & $-42,7142$ & 20 & Lowland forest & 3 & 0 \\
\hline Teresópolis & $-22,4122$ & $-42,9656$ & 871 & Altitude forest & 207 & 2.0 \\
\hline Três Rios & $-22,1167$ & $-43,2092$ & 269 & Altitude forest & 41 & 0 \\
\hline Vassouras & $-22,4039$ & $-43,6625$ & 434 & Altitude forest & 2 & 0 \\
\hline Total & & & & & 679 & 33.9 \\
\hline
\end{tabular}




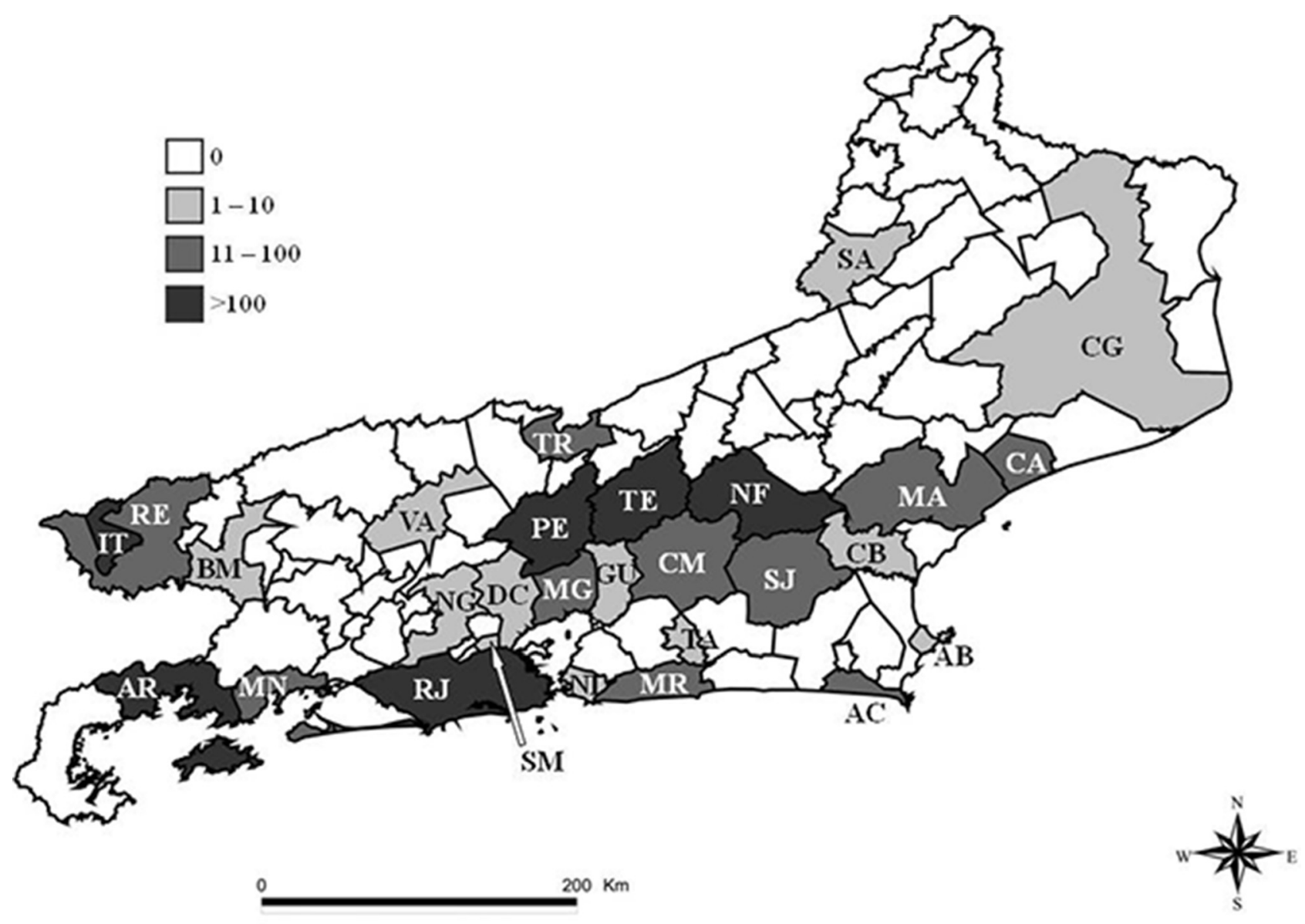

Figure 1. Map of the state of Rio de Janeiro, indicating the number of records of Arctiinae species in each municipality. AR: Angra dos Reis; AB: Armação dos Búzios; AC: Arraial do Cabo; BM: Barra Mansa; CM: Cachoeiras de Macacu; CG: Campos dos Goytacazes; CA: Carapebus; CB: Casimiro de Abreu; DC: Duque de Caxias; GU: Guapimirim; IT: Itatiaia; MA: Macaé; MG: Magé; MN: Mangaratiba; MR: Maricá; NI: Niterói; NF: Nova Friburgo; NG: Nova Iguaçu; PE: Petrópolis; RE: Resende; RJ: Rio de Janeiro; SA: Santo Antônio de Pádua; SM: São João de Meriti; SJ: Silva Jardim; TA: Tanguá; TE: Teresópolis; TR: Três Rios; VA: Vassouras. Cities without records of Arctiinae species are not indicated by abbreviations on the map.

Table 2. Matrix of dissimilarity between vegetation types in the state of Rio de Janeiro using Simpson's beta diversity index.

\begin{tabular}{lcc}
\hline & Altitude forest & Mixed formation \\
\hline Mixed formation & 0.22 & - \\
Lowland forest & 0.30 & 0.36 \\
\hline
\end{tabular}

\section{Discussion}

The Arctiinae fauna of the state of Rio de Janeiro compiled in this study represents $11 \%$ of the Arctiinae registered for the Neotropics (Jacobson \& Weller 2002) and about 50\% of the recorded fauna for Brazil (Ferro \& Diniz 2010). There are few lists of Arctiinae species for Brazilian states (e.g., Ferro \& Teston 2009), but the richness of these moths in the state of Rio de Janeiro is the largest ever recorded for a Brazilian state, with more than twice that observed in the state of Rio Grande do Sul (Ferro \& Teston 2009) and 1.4 times greater than that of
Santa Catarina (Ferro et al. 2012). The richness of the Arctiinae species in the state of Rio de Janeiro presented here is quite close to that for the state of São Paulo's estimated richness (Brown Jr. \& Freitas 1999), although the latter has approximately six times the area of the Rio de Janeiro (IBGE 2013). Indeed, the state of Rio de Janeiro has still areas well preserved from the Atlantic Forest and also has several research centers, these two facts can support this great diversity of Acrtiinae found in the state.

The three municipalities with the highest level of Arctiinae species richness in this study (Itatiaia, Petrópolis, and Angra dos Reis) showed the highest richness values for Arctiinae ever recorded at a single site collection from Brazil (Ferro \& Diniz 2007). According the Atlas of Forest Remnants of the Atlantic Forest (SOS Mata Atlântica \& INPE 2015), these three municipalities are located in areas that have the largest remaining forest in this biome; thus, they are municipalities with large areas of preserved Atlantic Forest. Besides being well preserved, these locations are very well sampled, which probably explains the richness of Arctiinae in these locations, 
especially Itatiaia, because of the insects that Zikán \& Zikán (1968) collected for 36 years in the Parque Nacional do Itatiaia area and its surroundings. Previous surveys of butterfly families, such as Lycaenidae (Duarte et al. 2009) and Pieridae (Monteiro et al. 2009), also highlight Itatiaia as a municipality with the highest number of recorded species of these insects. The small number of records in Nova Iguaçu and Guapimirim can be explained by the lack of Lepidoptera surveys in these regions, as there are still well-preserved forest remnants in these municipalities, such as Reserva Biológica Tinguá and the lowest part of the of Parque Nacional da Serra dos Órgãos, respectively. Municipalities without Arctiinae records match those where no survey of Lepidoptera has been conducted, and most have little or no forested areas, as in several municipalities north and west of the state (SOS Mata Atlântica \& INPE 2015).

In a study conducted with Arctiinae in the Atlantic Forest of southern Brazil, Ferro \& Teston (2009) found that 33\% of the species occurred in only one municipality, almost identical to the percentage observed in this study. The large number of species recorded exclusively in Itatiaia $(26.5 \%)$ may reflect the extensive survey of Lepidoptera species (Zikán \& Zikán 1968) or the high degree of endemism in the region.

The altitude forest had the highest number of Arctiinae records because it encompassed nine municipalities, including the best-sampled ones (Itatiaia and Petrópolis). Moreover, we must also consider the conservation status of these formations within the state, as the altitude forests represent the best preserved formation in the state of Rio de Janeiro, where the largest conservation areas in the state are concentrated (Itatiaia National Park and Serra dos Órgãos National Park). The mixed formation also encompassed municipalities that were well sampled, such as Angra dos Reis and Rio de Janeiro, which have areas in good condition within the state, such as Serra da Bocaina National Park and Tijuca National Park, respectively, which are protected. Moreover, lowland forests, including the sandbank formations, is one of the most degraded vegetation formations in the state, as it occurs in regions of high population density, high real estate value, accelerated deforestation, and forest fragmentation. In general, the remnants of sandbank formations in the state of Rio de Janeiro are located in patches of vegetation surrounded by urban or rural areas. The one large remaining sandbank conservation area in the state is the Restinga de Jurubatiba National Park.

After compiling existing records for Arctiinae moths in the State of Rio de Janeiro from Brazilian museum collections, data from the literature, and samplings, we obtained a list of 679 species. This species number was larger than any previously published list of Arctiinae in a Brazilian state. Although, several subsampled locations in the state lack surveys, such as Guapimirim, Nova Iguaçu, and Campos dos Goytacazes, which still have representative areas of Atlantic Forest vegetation. Our results indicate a wide variation in the Arctiinae dissimilarity values among the municipalities of the state of Rio de Janeiro. This pattern may reflect the low host specificity of the caterpillars and the small geographical size, although there is a large variation existing in relief of the state. If the results for the Arctiinae species represent a standard for other groups of Lepidoptera, or for insects as a whole, it is clear that host specificity is an issue that remains to be investigated.

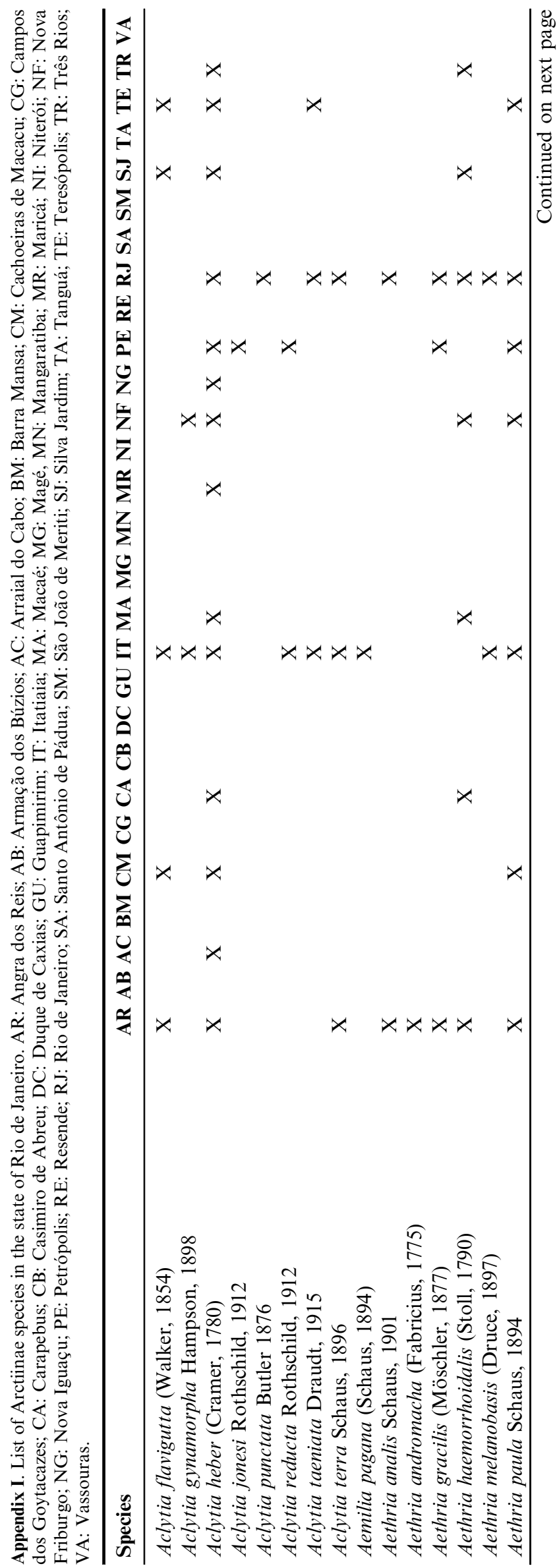


Biota Neotrop., 16(2): e20150112, 2016

Nascimento, M.S. et al.

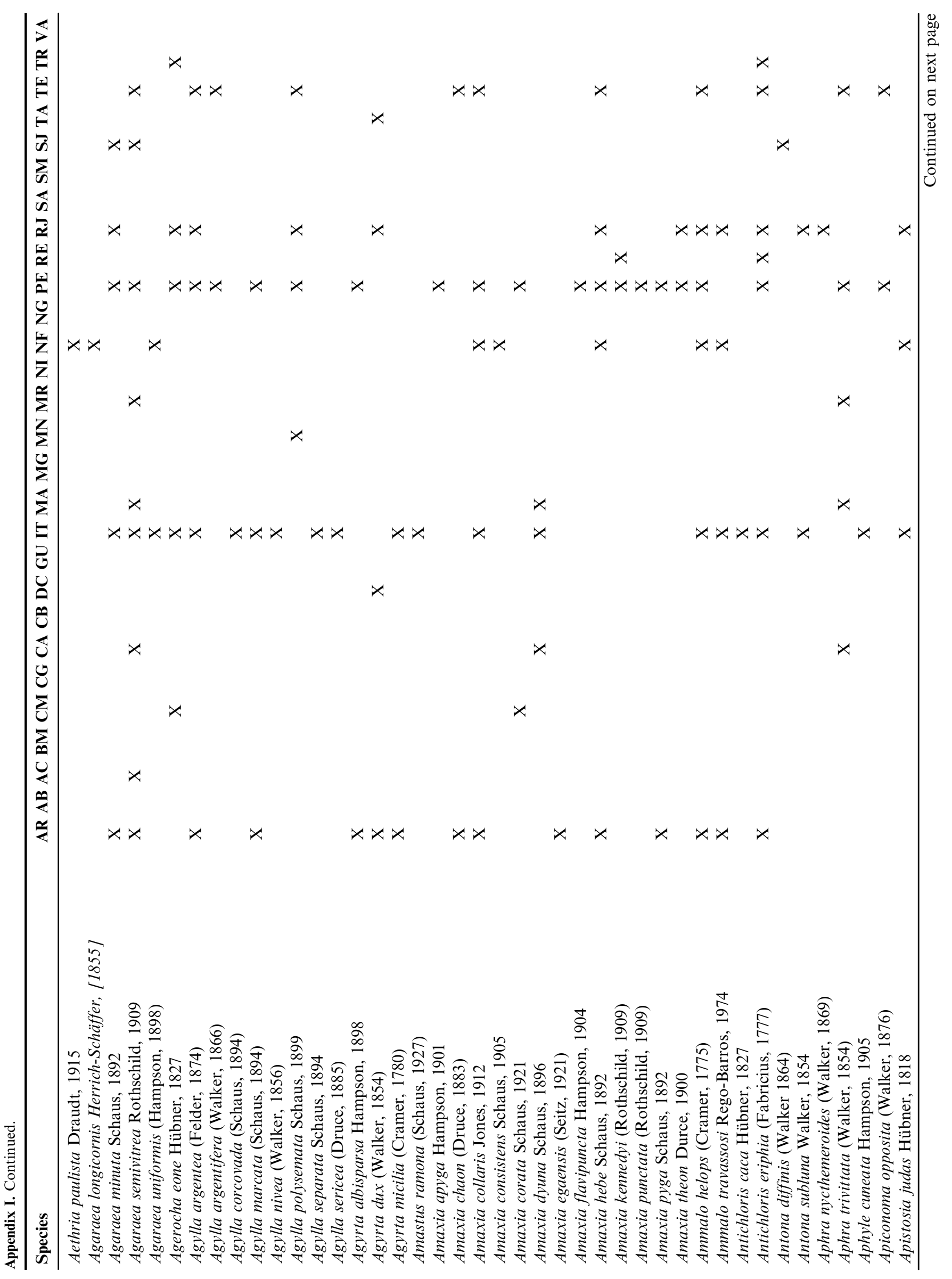

http://www.scielo.br/bn

http://dx.doi.org/10.1590/1676-0611-BN-2015-0112 
Biota Neotrop., 16(2): e20150112, 2016

Arctiinae of Rio de Janeiro, Brazil

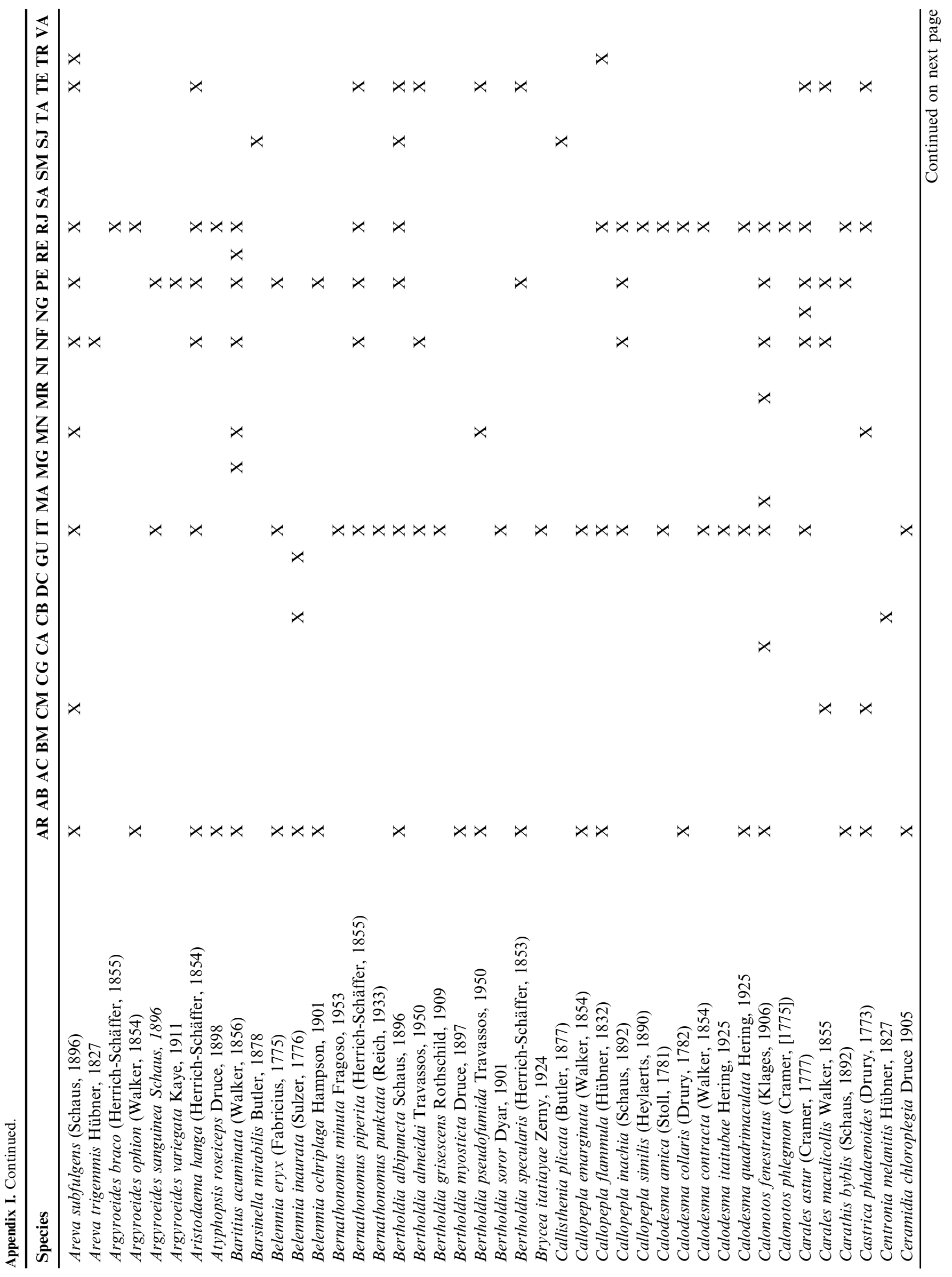

http://dx.doi.org/10.1590/1676-0611-BN-2015-0112

http://www.scielo.br/bn 
8

Biota Neotrop., 16(2): e20150112, 2016

Nascimento, M.S. et al.

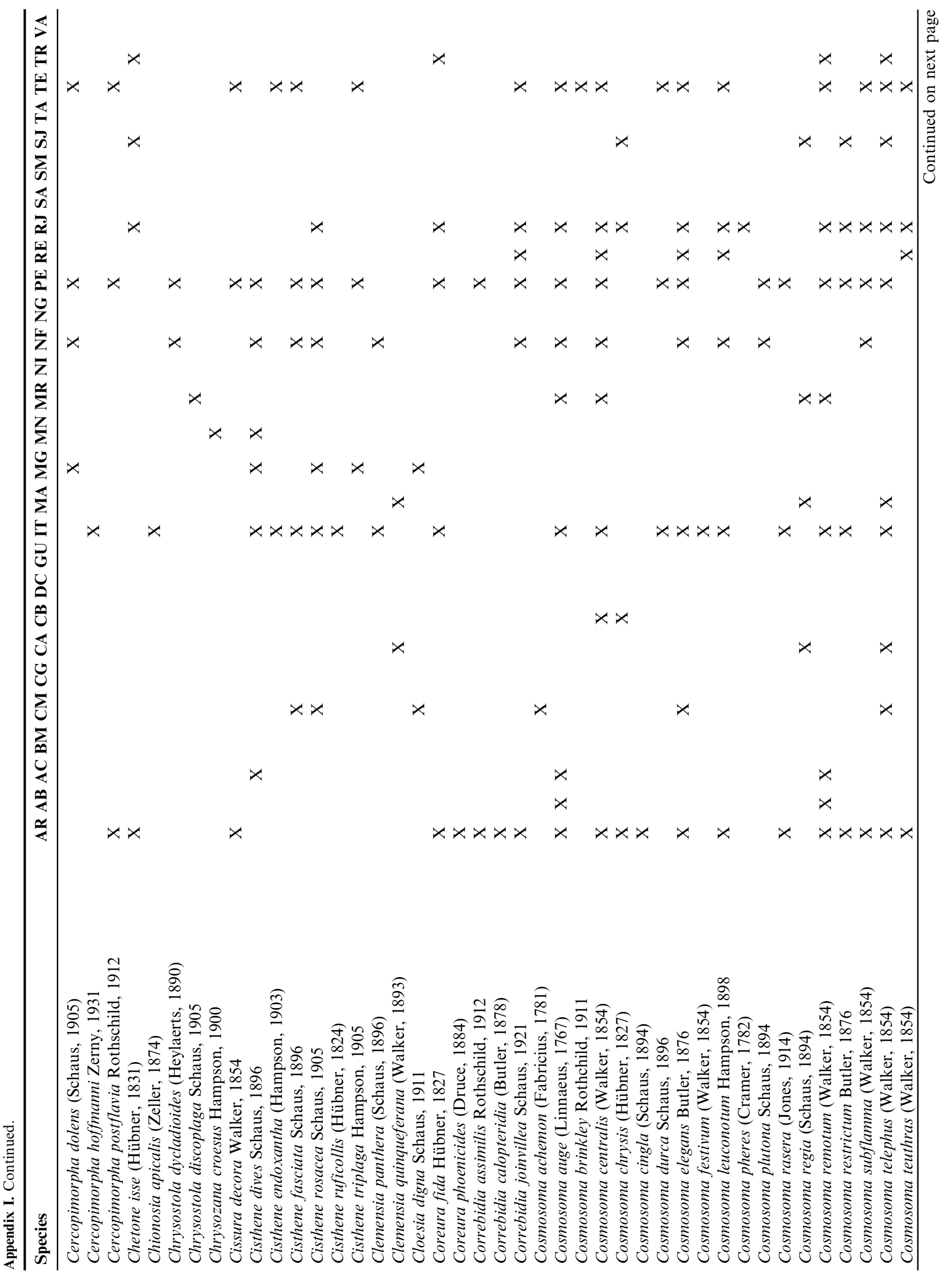

http://www.scielo.br/bn

http://dx.doi.org/10.1590/1676-0611-BN-2015-0112 
Biota Neotrop., 16(2): e20150112, 2016

9

Arctiinae of Rio de Janeiro, Brazil



http://dx.doi.org/10.1590/1676-0611-BN-2015-0112

http://www.scielo.br/bn 
10

Biota Neotrop., 16(2): e20150112, 2016

Nascimento, M.S. et al.



http://www.scielo.br/bn

http://dx.doi.org/10.1590/1676-0611-BN-2015-0112 
Biota Neotrop., 16(2): e20150112, 2016

11

Arctiinae of Rio de Janeiro, Brazil

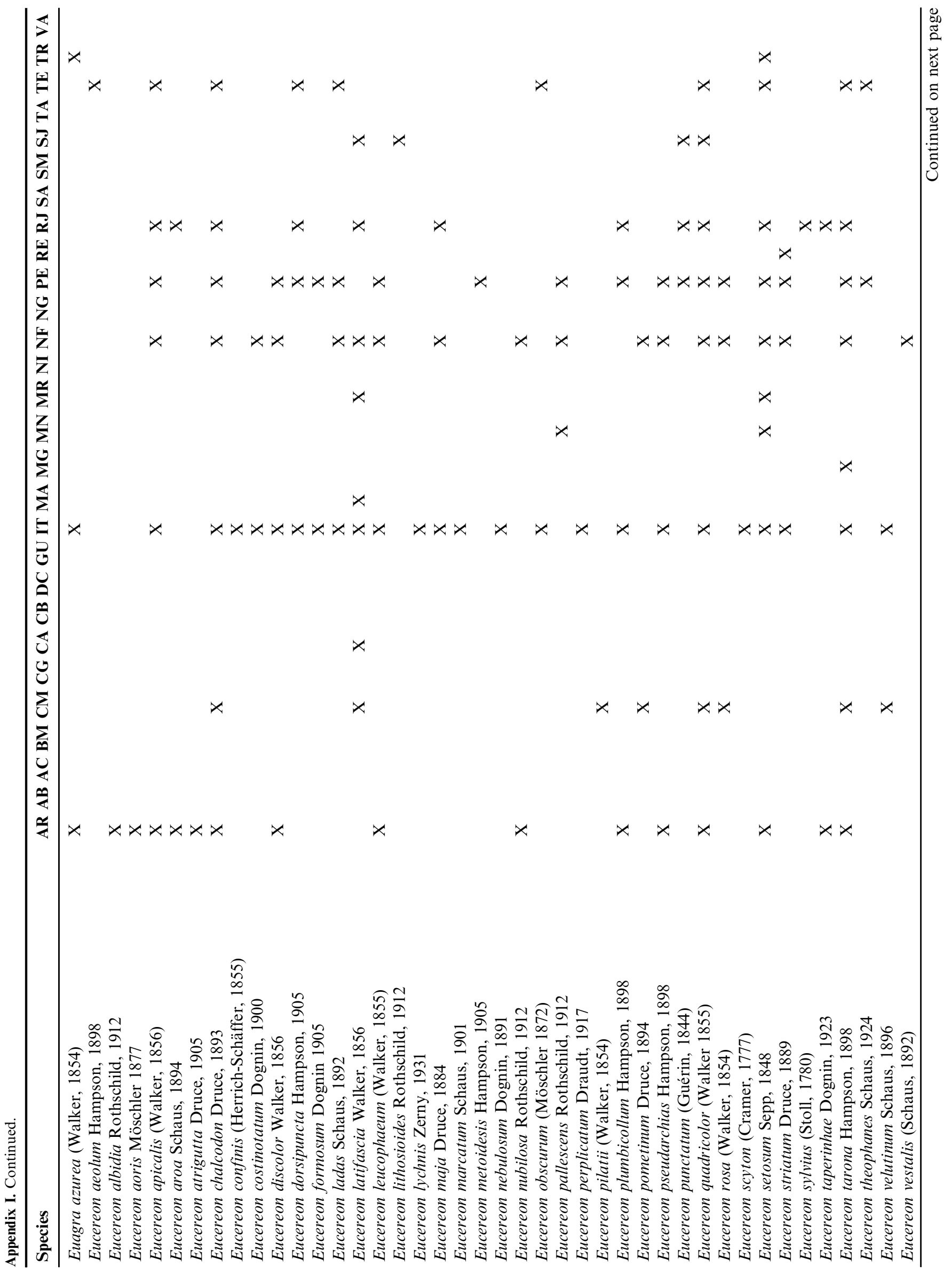

http://dx.doi.org/10.1590/1676-0611-BN-2015-0112

http://www.scielo.br/bn 
12

Biota Neotrop., 16(2): e20150112, 2016

Nascimento, M.S. et al.

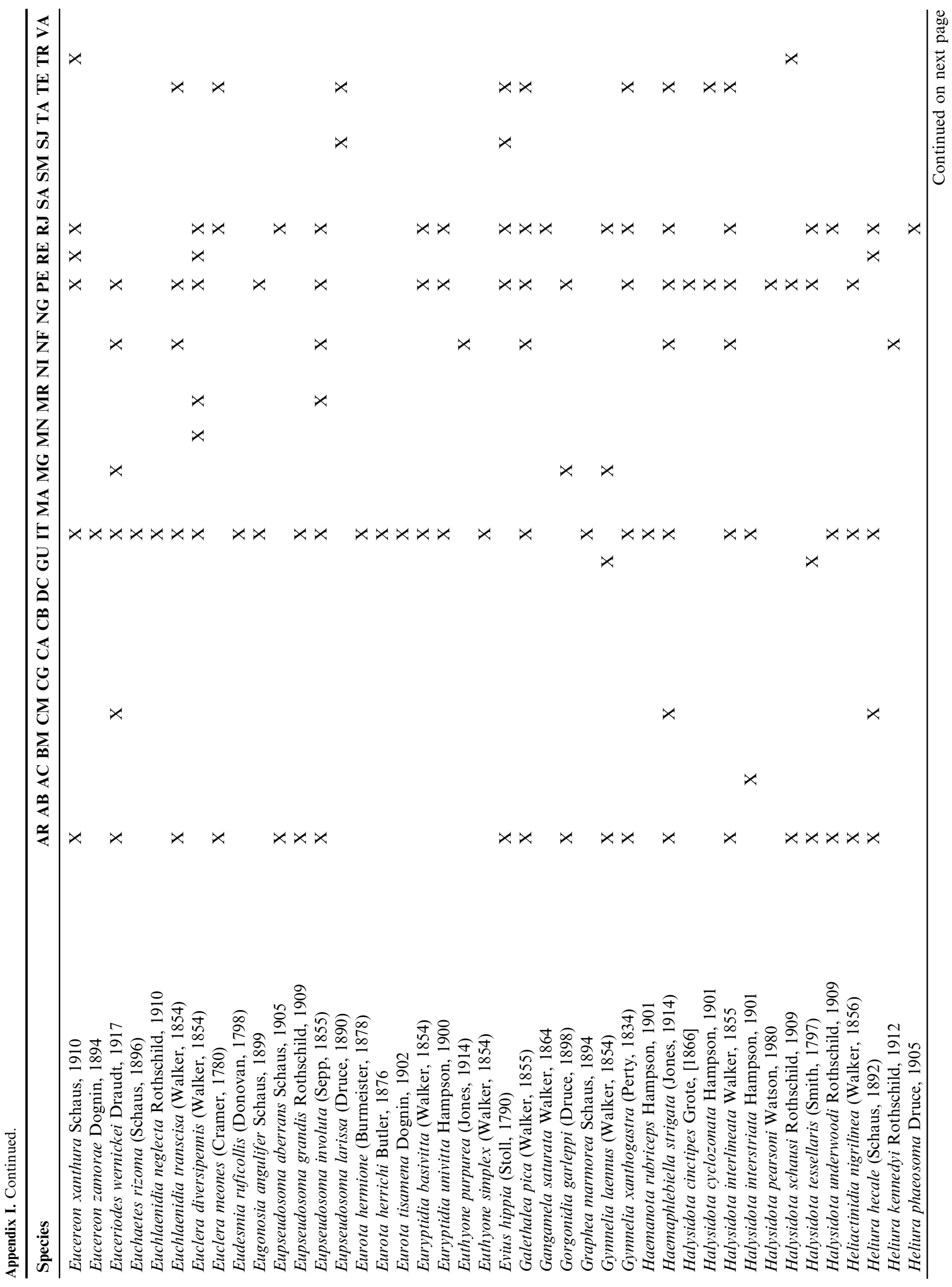

http://www.scielo.br/bn

http://dx.doi.org/10.1590/1676-0611-BN-2015-0112 
Biota Neotrop., 16(2): e20150112, 2016

13

Arctiinae of Rio de Janeiro, Brazil

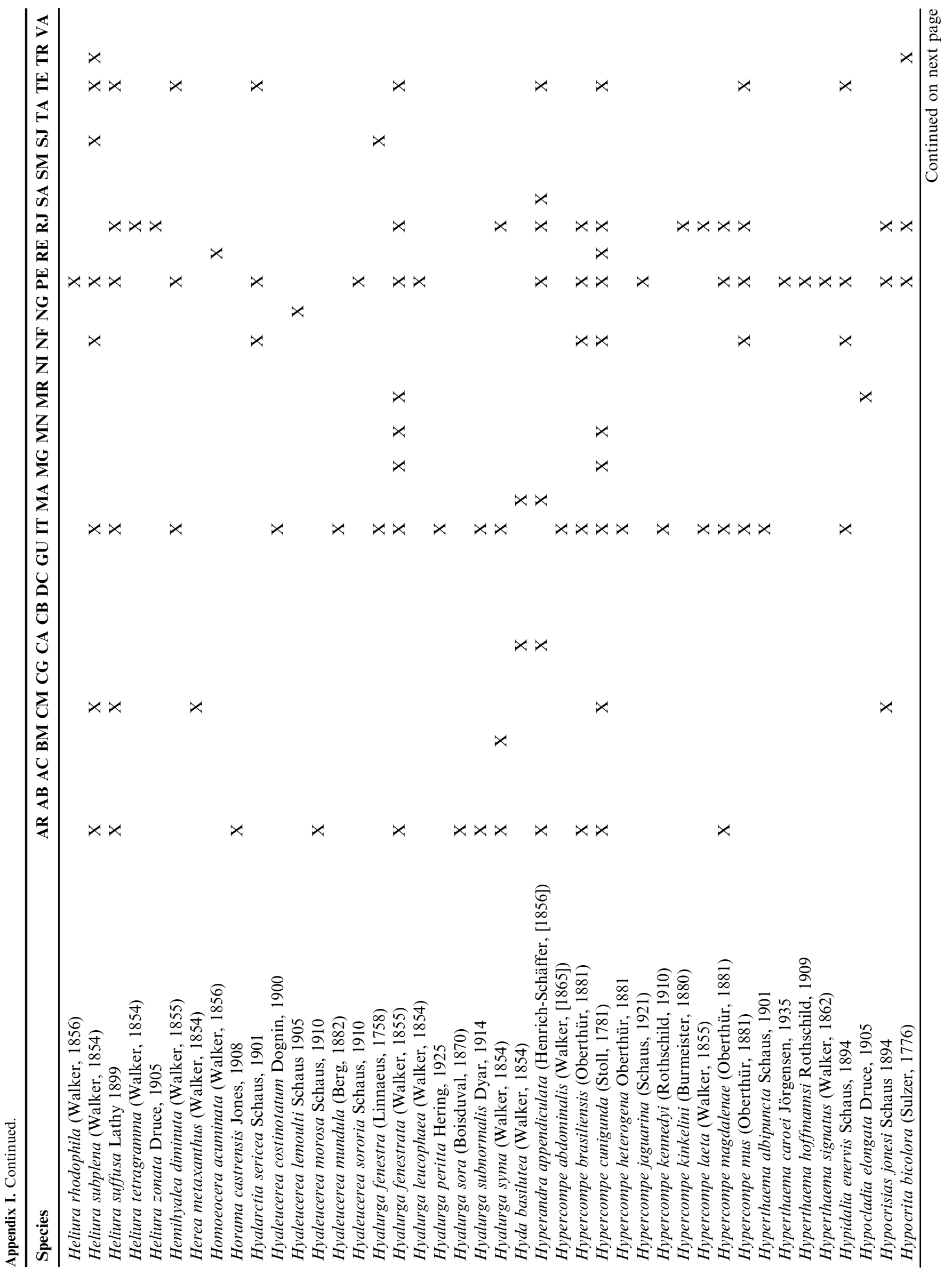

http://dx.doi.org/10.1590/1676-0611-BN-2015-0112

http://www.scielo.br/bn 
14

Biota Neotrop., 16(2): e20150112, 2016

Nascimento, M.S. et al.

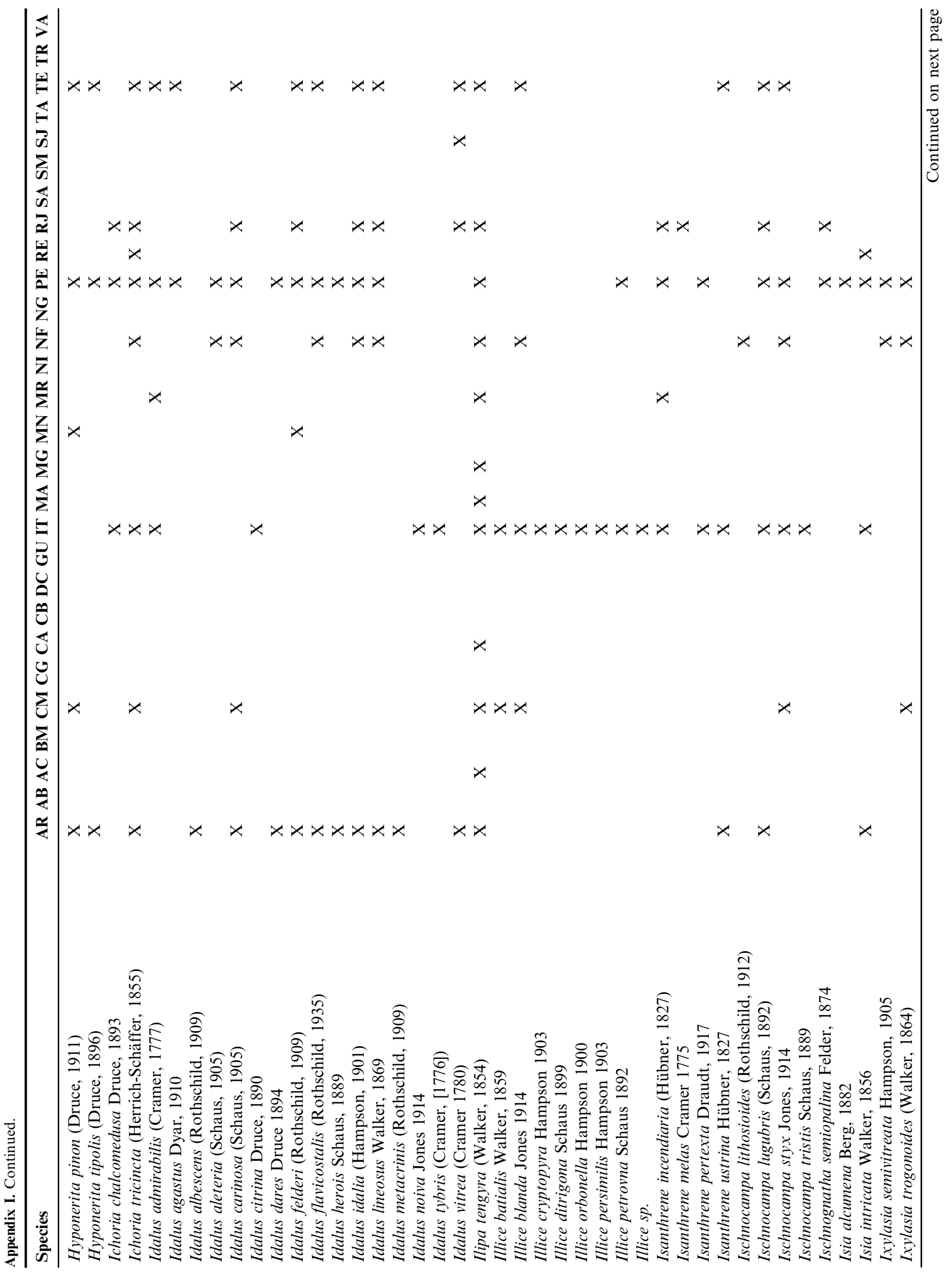

http://www.scielo.br/bn

http://dx.doi.org/10.1590/1676-0611-BN-2015-0112 
Biota Neotrop., 16(2): e20150112, 2016

15

Arctiinae of Rio de Janeiro, Brazil



http://dx.doi.org/10.1590/1676-0611-BN-2015-0112

http://www.scielo.br/bn 
16

Biota Neotrop., 16(2): e20150112, 2016

Nascimento, M.S. et al.



http://www.scielo.br/bn

http://dx.doi.org/10.1590/1676-0611-BN-2015-0112 
Biota Neotrop., 16(2): e20150112, 2016

17

Arctiinae of Rio de Janeiro, Brazil



http://dx.doi.org/10.1590/1676-0611-BN-2015-0112

http://www.scielo.br/bn 
18

Biota Neotrop., 16(2): e20150112, 2016

Nascimento, M.S. et al.

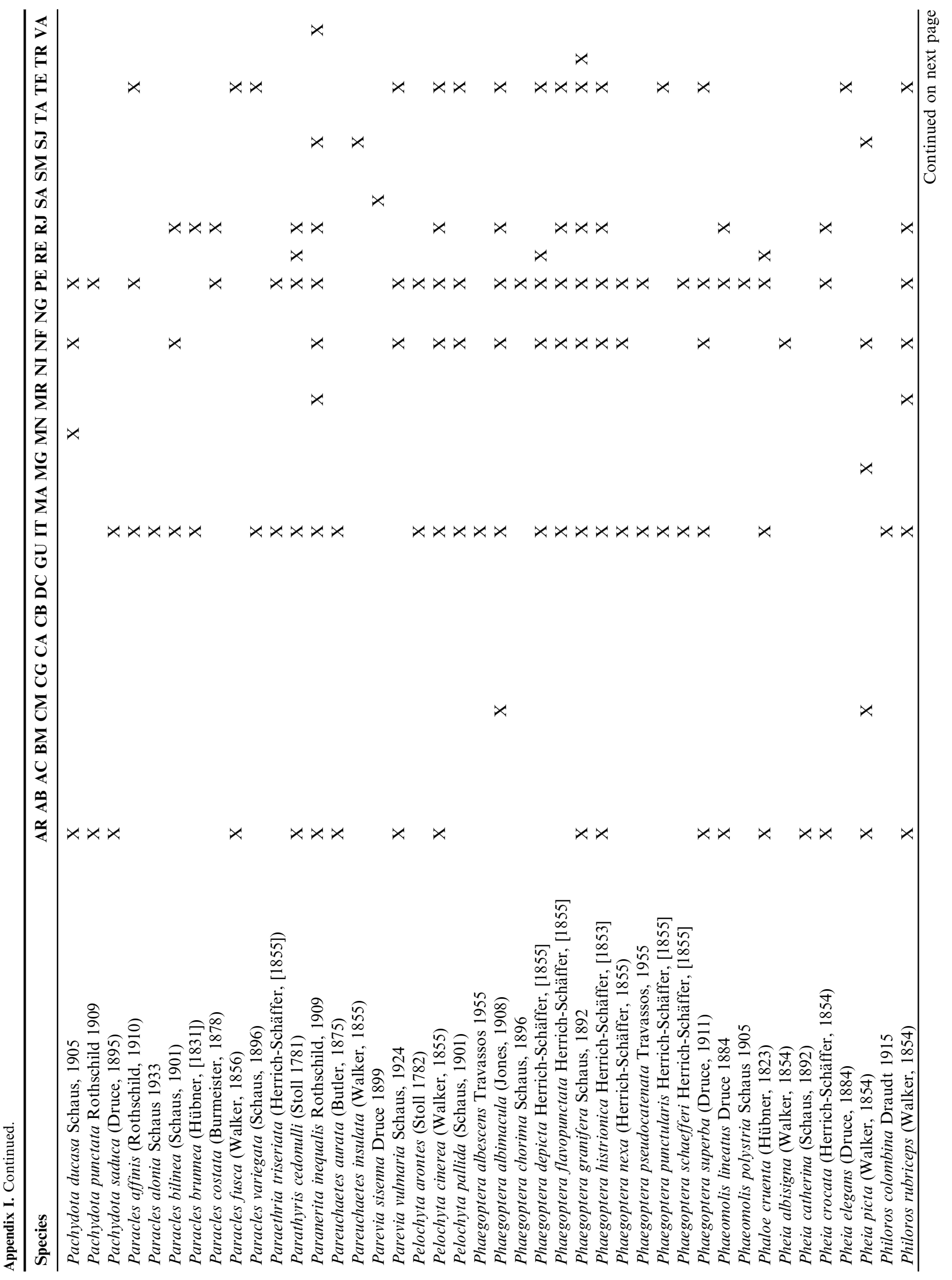

http://www.scielo.br/bn

http://dx.doi.org/10.1590/1676-0611-BN-2015-0112 
Biota Neotrop., 16(2): e20150112, 2016

19

Arctiinae of Rio de Janeiro, Brazil

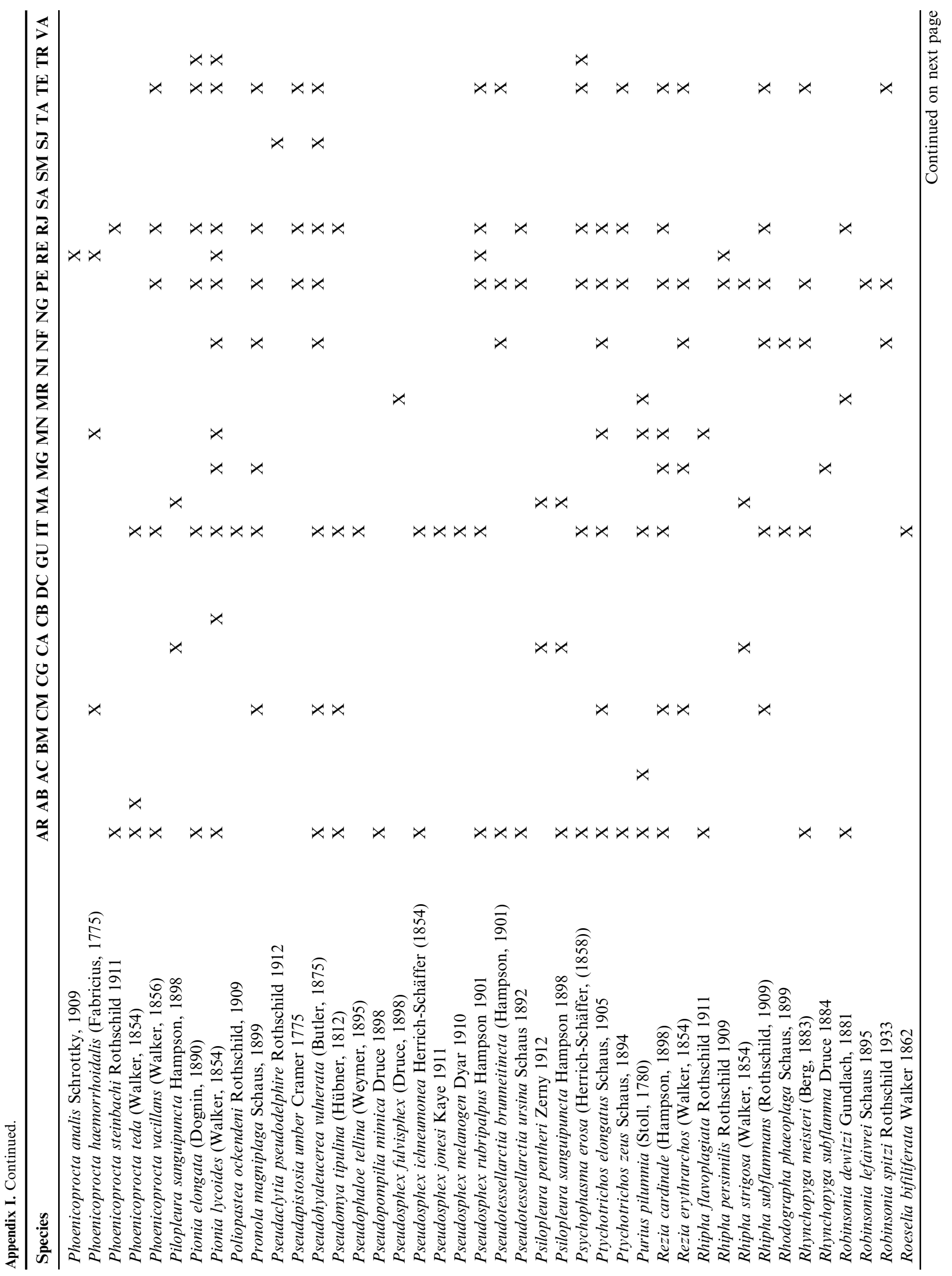

http://dx.doi.org/10.1590/1676-0611-BN-2015-0112

http://www.scielo.br/bn 
20

Biota Neotrop., 16(2): e20150112, 2016

Nascimento, M.S. et al.

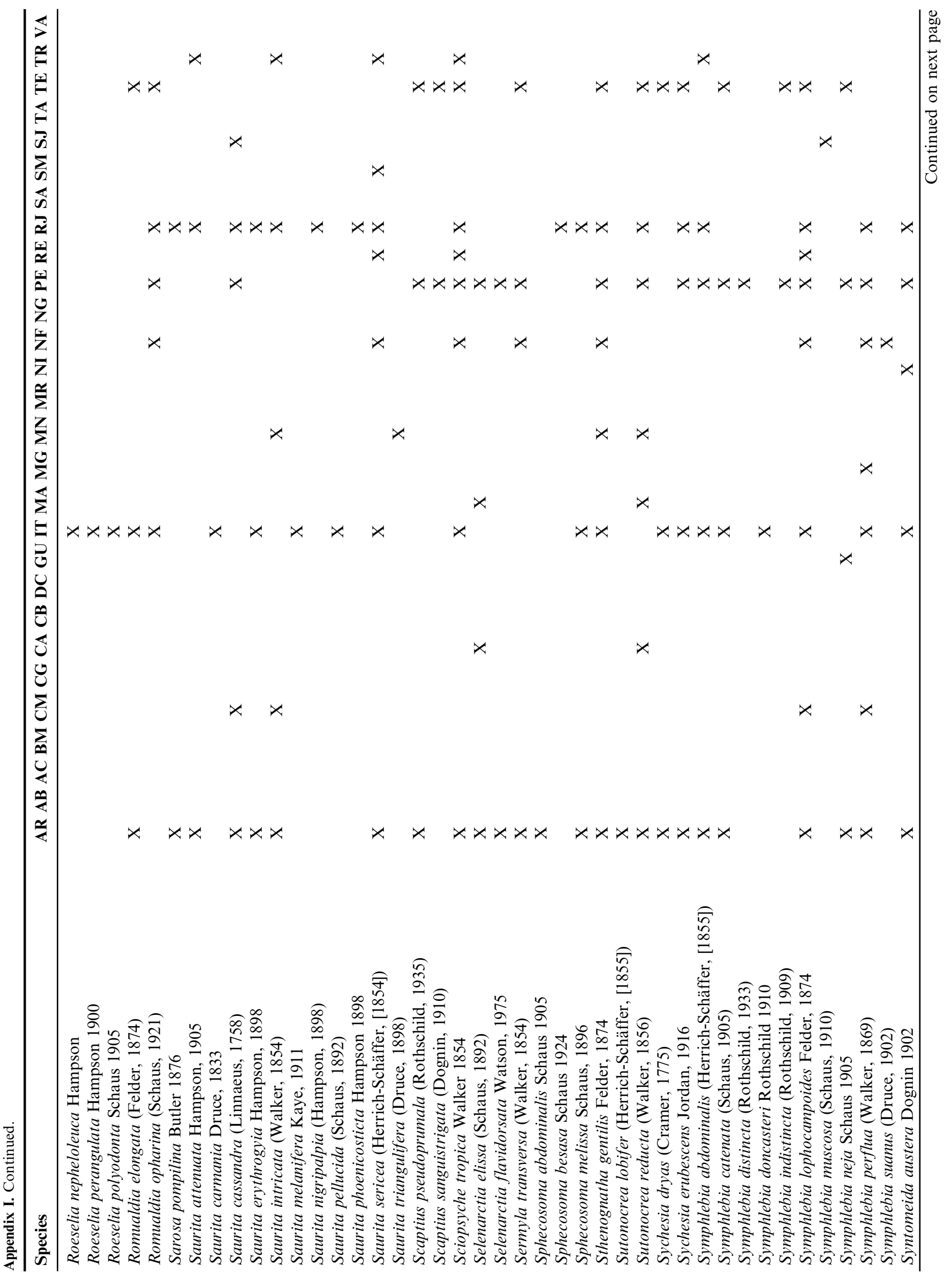

http://www.scielo.br/bn

http://dx.doi.org/10.1590/1676-0611-BN-2015-0112 
Biota Neotrop., 16(2): e20150112, 2016

21

Arctiinae of Rio de Janeiro, Brazil

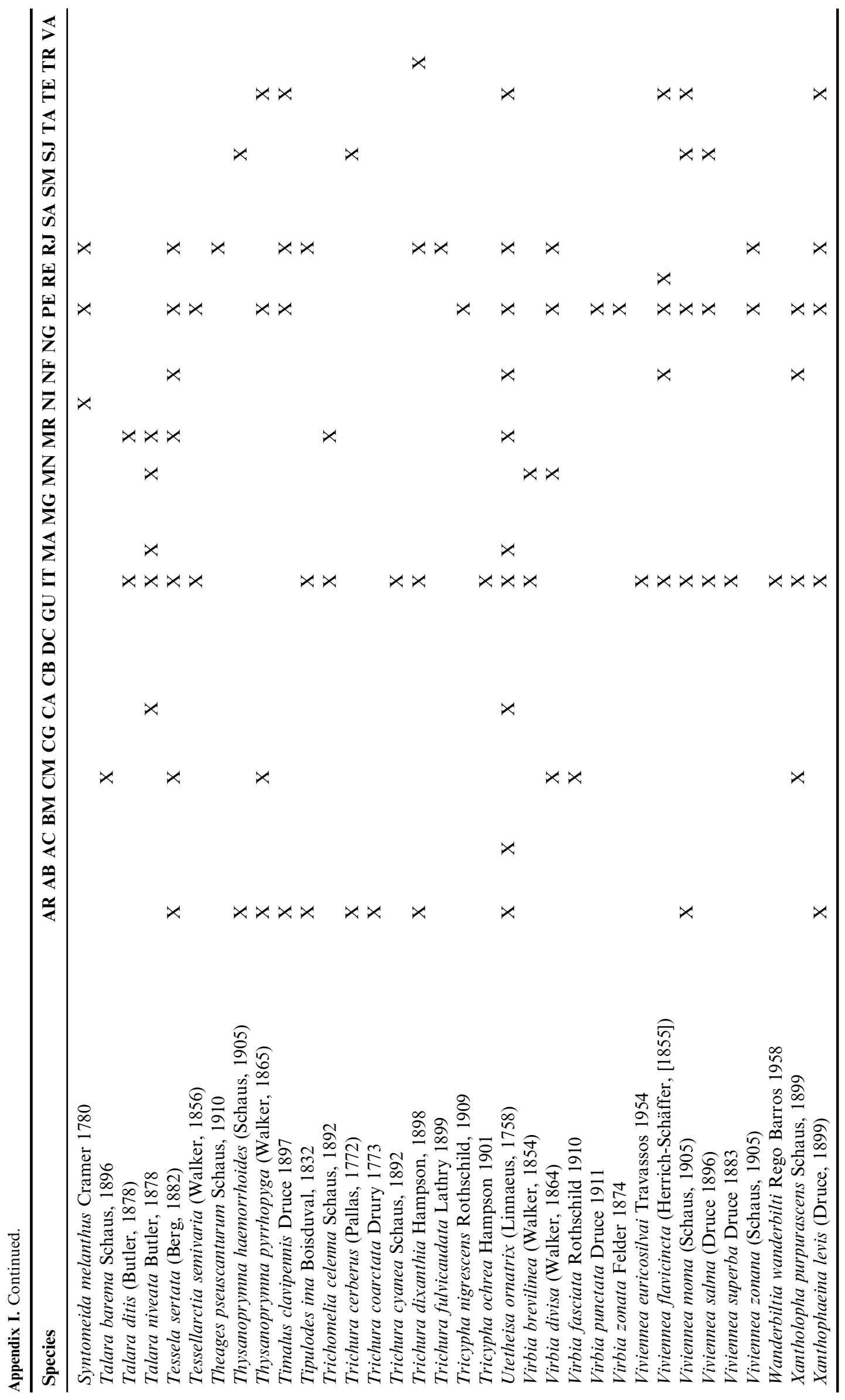

http://dx.doi.org/10.1590/1676-0611-BN-2015-0112

http://www.scielo.br/bn 


\section{Acknowledgments}

We would like to offer our sincere thanks to CAPES and to Programa de Pós-graduação em Ecologia (PPGE/UFRJ) for Milena S. Nascimento's doctoral scholarship and support. We also acknowledge CNPq for Ricardo F. Monteiro's scholarship research productivity. Finally, we thank INCT Hympar Sudeste $(\mathrm{CNPq} / \mathrm{FAPESP} / \mathrm{CAPES})$ for financing this research and ICMBio for the research permits in the União Biological Reserve, in Tinguá Biological Reserve and in Serra dos Órgãos National Park. RedeLep-CNPq (grant \#563332/2010-7) funded the Viviane Ferro work.

\section{References}

AB'SÁBER, A.N. 2005. Os Domínios de Natureza no Brasil: Potencialidades Paisagísticas. 3 ed. Ateliê Editorial, São Paulo.

BROWN JR, K.S. \& FREITAS, A.V.L. 1999. Lepidoptera. In Biodiversidade do Estado de São Paulo: Síntese do conhecimento ao final do século XX (C.R.F. Brandão \& E.M. Cancello, eds.). Fapesp, São Paulo, v. 5 , p. $225-243$.

DELFINA, M.C. \& TESTON, J.A. 2013. Arctiinae (Lepidoptera, Arctiidae) ocorrentes em uma área de pastagem na Amazônia Oriental em Altamira, Pará, Brasil. Acta Amazon. 43(1): 81-90, http://dx.doi.org/ 10.1590/S0044-59672013000100010

DUARTE, M., ROBBINS, R.K., FREITAS, A.V.L., BROWN, JR K.S., MONTEIRO, R.F., CASAGRANDE, M.M., MIELKE, O.H.H., NASCIMENTO, M.S. \& ALVES, T.G. 2009. Borboletas da Mata Atlântica do Estado do Rio de Janeiro: Lycaenidae (Lepidoptera). Arq. Mus. Nac. 67(3-4): 291-302.

FERRO, V.G. \& DINIZ, I.R. 2007. Arctiidae (Insecta: Lepidoptera) da Estação Biológica de Boracéia (Salesópolis, São Paulo, Brasil). Biota Neotrop. 7(3): 331-338 http://www.biotaneotropica.org. br/v7n3/pt/abstract?article + bn02207032007 (last accessed 10/05/ 2013), http://dx.doi.org/10.1590/S1676-06032007000300033

FERRO, V.G. \& DINIZ, I.R. 2010. Riqueza e composição das mariposas Arctiidae (Lepidoptera) no Cerrado. In Cerrado: conhecimento quantitativo como subsídio para as ações de conservação (I.R. Diniz, J. Marinho-Filho, R.B. Machado \& R. Cavalcanti, eds.). Editora Thesaurus, Brasília, p. 255-313.

FERRO, V.G. \& MELO, A.S. 2011. Diversity of tiger moths in a Neotropical hotspot: determinants of species composition and identification of biogeographic units. J. Insect Conserv. 15:643-651, http://dx.doi.org/10.1007/s10841-010-9363-6

FERRO, V.G. \& TESTON, J.A. 2009. Composição de espécies de Arctiidae (Lepidoptera) no sul do Brasil: Relação entre tipos de vegetação e entre a configuração espacial do hábitat. Rev. Bras. Entomol. 53(2): 278-286, http://dx.doi.org/10.1590/S0085-56262009000200010

FERRO, V.G., RESENDE, I.M.H. \& DUARTE, M. 2012. Mariposas Arctiinae (Lepidoptera: Erebidae) do estado de Santa Catarina, Brasil. Biota Neotrop. 12(4): 000-000 http://www.biotaneotropica.org.br/ v12n4/pt/abstract?article + bn01312042012 (last accessed 10/05/2013)., http://dx.doi.org/10.1590/S1676-06032012000400018

FERRO, V.G. \& ROMANOWSKI, H.P. 2012. Diversity and composition of tiger moths (Lepidoptera: Arctiidae) in an area of Atlantic Forest in southern Brazil: is the fauna more diverse in the grassland or in the forest? Zoologia 29(1): 7-18, http://dx.doi.org/10.1590/ S1984-46702012000100002

GALINDO-LEAL, C. \& CÂMARA, I.G. 2005. Status do hotspot Mata Atlântica: Uma síntese. In Mata Atlântica: Biodiversidade, Ameaças e Perspectivas (C. Galindo-Leal \& I.G. Câmara, orgs.). Fundação SOS Mata Atlântica e Conservação Internacional, São Paulo, p. 3-11.

IBGE. 2013. Resolução N ${ }^{\circ} 1$ do Instituto Brasileiro de Geografia e Estatística, de 15 de Janeiro de 2013 - Área Territorial Oficial. Diário Oficial da União, Brasília, DF.
JACOBSON, N.L. \& WELLER, S.J. 2002. A cladistic study of the Arctiidae (Lepidoptera) by using characters of immatures and adults. Thom. Say P: monographs. Lanham, pp 97.

KOLEFF, P., GASTON, K.J. \& LENNON, J.J. 2003. Measuring beta diversity for presence-absence data. J. Anim. Ecol. 72(3): 367-382, http://dx.doi.org/10.1046/j.1365-2656.2003.00710.x

LEWINSOHN, T.M. \& PRADO, P.I. 2004. Biodiversidade Brasileira: Síntese do Estado Atual do Conhecimento. 2 ed. Editora Contexto, São Paulo.

LEWINSOHN, T.M., FREITAS, A.V.L. \& PRADO, P.I. 2005. Conservação de invertebrados terrestres e seus habitats no Brasil. Megadiv. 1(1): 62-69.

MONTEIRO, R.F., ESPERANÇO, A.P., BECKER, V.O., OTERO, L.S., HERKENHOFF, E.V. \& SOARES, A. 2004. Mariposas e borboletas na Restinga de Jurubatiba. In Pesquisas de Longa Duração na Restinga de Jurubatiba - Ecologia, História Natural e Conservação (C.F.D. Rocha, F.A. Esteves \& F.R. Scarano, eds.). Rima Editora, São Carlos. p. 143-164.

MONTEIRO, R.F., FREITAS, A.V.L., COSTA FILHO, M.A.F, NASCIMENTO, M.S., ALVES, T.G., BROWN, JR K.S., MIELKE, O.H.H., CASAGRANDE, M.M. \& DUARTE, M. 2009. Borboletas da Mata Atlântica do Estado do Rio de Janeiro: Pieridae (Lepidoptera). Arq. Mus. Nac. 67(3-4): 283-289.

MORENO, C., MAGALHÃES, F.C., REZENDE, L.H.G., NEVES, K. \& FERRO, V.G. 2015. Riqueza e composição de Arctiinae (Lepidoptera, Erebidae) em cinco Unidades de Conservação do Cerrado. Iheringia Ser. Zool. 105(3):297-306, http://dx.doi.org/10.1590/1678476620151053297306

MYERS, N., MITTERMEIER, R.A., MITTERMEIER, C.G., FONSECA, G.A.B. \& KENT, J. 2000. Biodiversity hotspots for conservation priorities. Nature 403: 853-858, http://dx.doi.org/10.1038/ 35002501

OLIVEIRA-FILHO, A.T. \& FONTES, M.A.L. 2000. Patterns of floristic differentiation among Atlantic forests in southeastern Brazil and the influence of climate. Biotropica 32(4): 793-810, doi: http://dx.doi.org/10.1646/0006-3606(2000)032[0793:POFDAA] 2.0.CO;2

PIÑAS-RUBIO, F. \& MANZANO, P.I. 2003. Mariposas del Ecuador, Arctiidae, Subfamília: Ctenuchinae. Conpañia de Jesús, Quito., http://dx.doi.org/10.1007/s10841-010-9363-6

PIÑAS-RUBIO, F., RAB-GREEN, S., ONORE, G. \& MANZANO, P.I. 2000. Mariposas Del Ecuador. Arctiidae, Subfamilias: Arctiinae y Pericopinae. Pontificia Universidad Católica del Ecuador, Quito.

R DEVELOPMENT CORE TEAM. 2009. R: A language and environment for statistical computing. R Foundation for Statistical Computing, Vienna. http://www.R-project.org (last accessed 30/08/ 2011).

SOS MATA ATLÂNTICA \& INPE. 2015. Atlas dos Remanescentes Florestais da Mata Atlântica Período 2013-2014, Fundação SOS Mata Atlântica e Instituto Nacional de Pesquisas Espaciais. Disponível em http://mapas.sosma.org.br/ dados/ (last accessed 18/02/2016).

TESTON, J.A. \& CORREA, D.C.V. 2015. The Arctiini (Lepidoptera, Erebidae, Arctiinae) fauna of the Serra do Pardo National Park, Pará, Brazil. Check List 11(2): 1613, http://dx.doi.org/10.15560/ 11.2.1613

TESTON, J.A. \& DELFINA, M.C. 2010. Diversidade de Arctiinae (Lepidoptera, Arctiidae) em área alterada em Altamira, Amazônia Oriental, Pará, Brasil. Acta Amazon. 40(2): 387-396, http://dx.doi.org/10.1590/S0044-59672010000200017

VINCENT, B. \& LAGUERRE, M. 2014. Catalogue of the Neotropical Arctiini Leach, [1815] (except Ctenuchina Kirby, 1837 and Euchromiina Butler, 1876) (Insecta, Lepidoptera, Erebidae, Arctiinae). ZOOSYSTEMA 36(2): 137-533, http://dx.doi.org/ 10.5252/z2014n2a 1 
WATSON, A. \& GOODGER, D.T. 1986. Catalogue of the Neotropical tiger-moths. Occas. Pap. Syst. Entomol. 1: 1-70.

ZENKER, M.M., DEVRIES, P.J., PENZ, C.M., TESTON, J.A., FREITAS, A.V.L. \& PIE, M.R. 2015. Diversity and composition of Arctiinae moth assemblages along elevational and spatial dimensions in Brazilian Atlantic Forest. J. Insect Conserv. 19:129-140, http://dx.doi. org/10.1007/s10841-015-9753-x

ZIKÁN, J.F. \& ZIKÁN, W. 1968. Inseto-fauna do Itatiaia e da Mantiqueira 3: Lepidoptera. Pesqui. Agropecu. Bras. 3: 45-109.

Received 23/09/2015

Revised 19/02/2016

Accepted 16/05/2016 